Reproduction of the Map attached to the Convention between Great Britain and China signed at Peking on the $9^{\text {th }}$ of Jume 1898

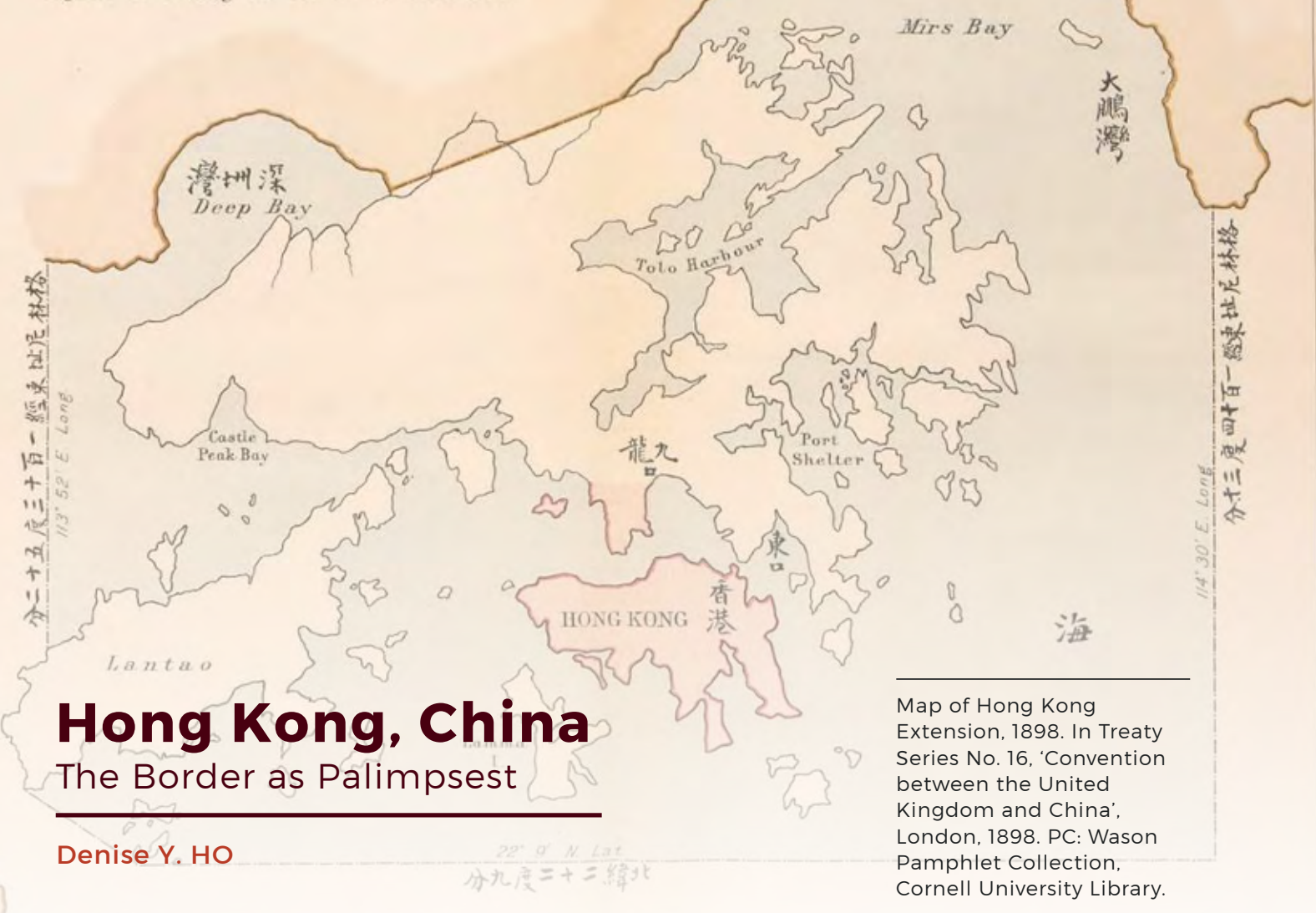

$\mathrm{n}$ the late morning of 11 March 1899, Hong Kong's Colonial Secretary James Stewart Lockhart and Huang Zongxin, a representative of the Governor General at Canton in China's Guangdong Province, met in Lockhart's council chamber. Both men produced maps of China's Xin'an (新安) County as guides to their discussion of the boundaries of the New Territories-an extension of colonial Hong Kong into China's mainland. Unlike Hong Kong Island and the Kowloon Peninsula, ceded in 1842 and 1860, respectively, as a result of the Opium Wars, the New Territories were leased in 1898 for a period of 99 years. But the 1898 treaty left the exact border to be determined. At this meeting and one following, Huang was concerned with technicalities of governance, like the collection of taxes and rents, the pursuit of pirates in territorial waters, and the location of customs stations. Lockhart, by contrast, was interested in maximising British territory. He proposed a boundary line that would not only join Mirs Bay (大鹏湾) to the east and Deep Bay (后海湾, today 深圳湾) to the west, but also extend north of the Shenzhen River and encompass the market towns of Shenzhen (深圳) and Shatoujiao (沙头角) (Colonial Office 1898-1900: 118-22).

But when Lockhart and Huang concluded their negotiations, the British did not receive any more of Xin'an County, nor did they gain Shenzhen as a strategic base (Colonial Office 1898-1900: 32-33, 130-31). The Hong KongChina border was established as the maritime high-tide mark in each bay, the Shenzhen River and its banks, and a remote frontier with 
numbered stones marking the 'Anglo-Chinese Boundary'. Two important understandings underlay the demarcation: that roads and waters were to remain accessible to inhabitants on both sides, and that the British would respect local customs and property (Colonial Office 1898-1900: 132-34).

Over its 99-year history and into the present day, the border witnessed dramatic political change. Beginning as a boundary between the British Empire and the Manchu Qing, the Hong Kong-China border went on to divide a waning imperial redoubt and Nationalist and later Communist China. With the 1997 Handover, it finally became an internal border, separating the Hong Kong Special Administrative Region from the Shenzhen Special Economic Zone. Throughout, the boundary has been both physical and imagined, though even the physical border could shift with the silting of waters and the rebuilding of fences. The border was once open and later militarised, with barbed wire and restricted zones. While local residents contended with its materiality, people across Hong Kong and in Xin'an-later Bao'an (宝安)-County still lived with the imagination of it, especially those with crossborder families. For those living on either side, the border was a liminal zone spatially and temporally, always due to return to Chinese territory.

\section{International Boundary}

Long before Lockhart and Huang marked the 1898 boundary, Hong Kong was already a node in international trading systems, serving as a conduit for Britain's China trade as well as a channel for regional trade between North and South China, and between China and Southeast Asia. Historian Elizabeth Sinn describes Hong Kong as a 'space of flow', linking China with what she calls the 'Cantonese Pacific', sending thousands of emigrants to seek their fortunes in Californian goldmines and later receiving their bones for hometown burials (2013: 11, 47-50).
The lease of the New Territories accelerated the development of transportation networks, culminating in the building of the KowloonCanton Railway, with the British section opening in 1910 and the Chinese section in 1911 (Colonial Office 1907). A 1923 Chinese travel guide traces the railway journey, with the products for sale at each station revealing the modest agricultural communities that lined its path. On the Chinese side, Shenzhen's market town offered sugarcane, birdseed, pears, dried oysters, and peanuts. On the British side, Sheung Shui station exported salt fish for bean cakes and miscellaneous goods (Traveller's Guide to the Kowloon-Canton Railway 1923: 535-36). Though Bao'an County never had Hong Kong's stature as an international port, it had numerous ferry routes that connected to Hong Kong, linked further up the Pearl River to Dongguan and Guangzhou, and brought in agricultural products from Huiyang and environs. On the eve of the Second Sino-Japanese War in 1937, the county had three main public roads, with two more under construction and two in the planning stages (Department of Agriculture, Zhongshan National University 1937: 4-5). While people living along the physical borderlike those in the divided village of Shatoujiao/ Sha Tau Kok-endured the burden and expense of customs posts, others across Hong Kong and China benefited from the affordances of the border: the movement of people, goods, remittances, and more (Hase 1993: 157-61).

The Hong Kong-China border was thus a gateway for trade and migration. Between the outbreak of World War I in 1914 and the Japanese occupation in 1941, Hong Kong's population grew from 500,000 to 1.5 million (Faure 1997: 149). Hong Kong's relative stability during China's warlord periodbefore the establishment of the Nationalist government in 1927-coupled with its early industrialisation, made it a draw for Chinese labour, from men for its shipping industry to women in service work. The mobility of crossborder labour became evident in the seamen's strikes of the 1920s, when protests against British imperialism linked Hong Kong's 
Chinese Seamen's Union with Chinese unions and the government in Guangdong. First in 1922 and then in 1925, striking Hong Kong workers simply crossed the border to China, where they had the opportunity to organise and rally public opinion (Tsin 2003: 78-80; Faure 1997: 166-74). But it was Japan's invasion of China in 1937 that caused Hong Kong's population to swell with wartime migrants, filling government-run refugee camps and straining the food supply. After Hong Kong fell to the Japanese on Christmas Day 1941, some refugees chose to return to China and crossed the border in the other direction. Ubiquitous in oral histories recorded in both Hong Kong and China are tales of flight, on foot and by boat. The oystermen who worked both sides of Deep Bay, for example, recall fleeing Shajing on the Chinese coast for Lau Fau Shan (罗浮山) on the Hong Kong side, returning like the tides after the Japanese passed through (Bai 2012: 27, 39-40).

As an international boundary, the Hong Kong-China border was both bounded and traversed by Chinese politics. Revolutionaries like China's 'founding father' Sun Yat-sen used Hong Kong as a base and political platform, while warlords came to Hong Kong to seek refuge from political enemies (Lary 2005: 158-59). During and after the Japanese invasion, Hong Kong was an important site for both the Nationalists and the Communists. The Chinese Communist Party (CCP), driven underground and into the countryside by the ruling Nationalists, used Hong Kong both for organising military operations-including purchasing for the Eighth Route Army-and for propaganda and publishing (Loh 2010: 5859). Perhaps the most symbolic cross-border political movement during this period was the anti-Japanese guerilla resistance, whose area of operation stretched from the Pearl River Delta into Japanese-occupied Hong Kong, and from the rural New Territories to urban Kowloon (Loh 2010: 59-63; Chan 2009). The East River Column-about 5,000 full-time soldiers under the direction of the $\mathrm{CCP}-$ became legend in local revolutionary lore
(Bao'an County Gazetteer 1960: 78-79). While later CCP history claimed the work of the East River Column was peasant resistance against imperialism, recent oral histories reveal a patriotism that was far simpler. New Territories villager Zhang Guanfu (Cheung Koon Fu, b. 1921), who joined the Shatoujiao/Sha Tau Kok squadron in 1943 by sailing across Mirs Bay to train at Yantian, remembers: 'Before I joined the guerrillas I didn't know anything ... I knew there was someone called Chiang Kai-shek and someone called Mao Zedong' (Cheung 2011). Later responsible for teaching literacy classes and manning the communication station in his home village, he remarked that joining the guerrillas was a matter of sheer survival: 'The guerrillas weren't doing anything bad, just saving the nation' (Cheung 2011).

\section{Ideological Line}

Before the People's Republic of China was established in 1949, the Hong Kong-China border remained relatively open. But with the outbreak of the Korean War and the onset of the global Cold War, the border hardened. After the liberation of Shenzhen in October 1949, direct train and ferry services ended, with the automobile crossing at Wenjindu/Man Kam To (文锦渡) closing in May 1950. Travellers going in and out of China crossed at Luohu/ Lo Wu (罗湖), disembarking from the train and crossing the border on foot (He 1993: 176). Both China and Hong Kong instituted a system of travel passes required to enter their respective frontier zones, with additional exit and entry permits required to cross the border itself. On the Hong Kong side, British officials instituted a quota system, allowing 50 Cantonese into Hong Kong per day, with entry permits required of all others (Director of Immigration 1965: 1-5). On the Chinese side, permits were required to enter Guangdong Province, exit papers were issued by the Shenzhen police, and a British entry permit was technically needed to pass the Chinese border officials- 
though this last hurdle could be cleared with a bribe to the Yellow Ox Gang (CIA 1952). In addition to limitations on passenger traffic, the movement of goods was curtailed in 1950 and 1951 by an American and United Nations embargo related to the Korean War, as well as by the protectionist policies of the New China (Glennon et al. 1983: 1954-63).

The border as an ideological line was reinforced by restrictions on movement and goods. The divide between Hong Kong and China also hardened in material terms, with major construction on the Hong Kong frontier fence in 1952 and then at the beginning of the Cultural Revolution in 1966 (Hong Kong Public Records Office, HKRS 842-12-1). The land border was guarded, but not in a continuous line: on the Chinese side, it was patrolled by border soldiers and villagers in the People's Militia; on the Hong Kong side, policemen were stationed at border posts. There were occasional flareups at the border, most notably at Shatoujiao/ Sha Tau Kok in 1967. But everyday life along the frontier was characterised as much by porousness as by a boundary. Smuggling was pervasive, from China's encouragement to evade the Korean War blockade to streams of commodities that crossed in travellers' luggage (Thai 2018: 244, 253-59). Farmers on both sides of the border made daily crossings to work land on the other side-for example, Bao'an County peasants worked an estimated 4,000 $\mathrm{mu}$ (about 162 hectares) of land in the New Territories (Shenzhen Museum 2014: 247). In 1961, Bao'an County's Party Committee made smallscale cross-border trade a matter of policy, permitting residents within 10 kilometres of the border to make five trips a month, with

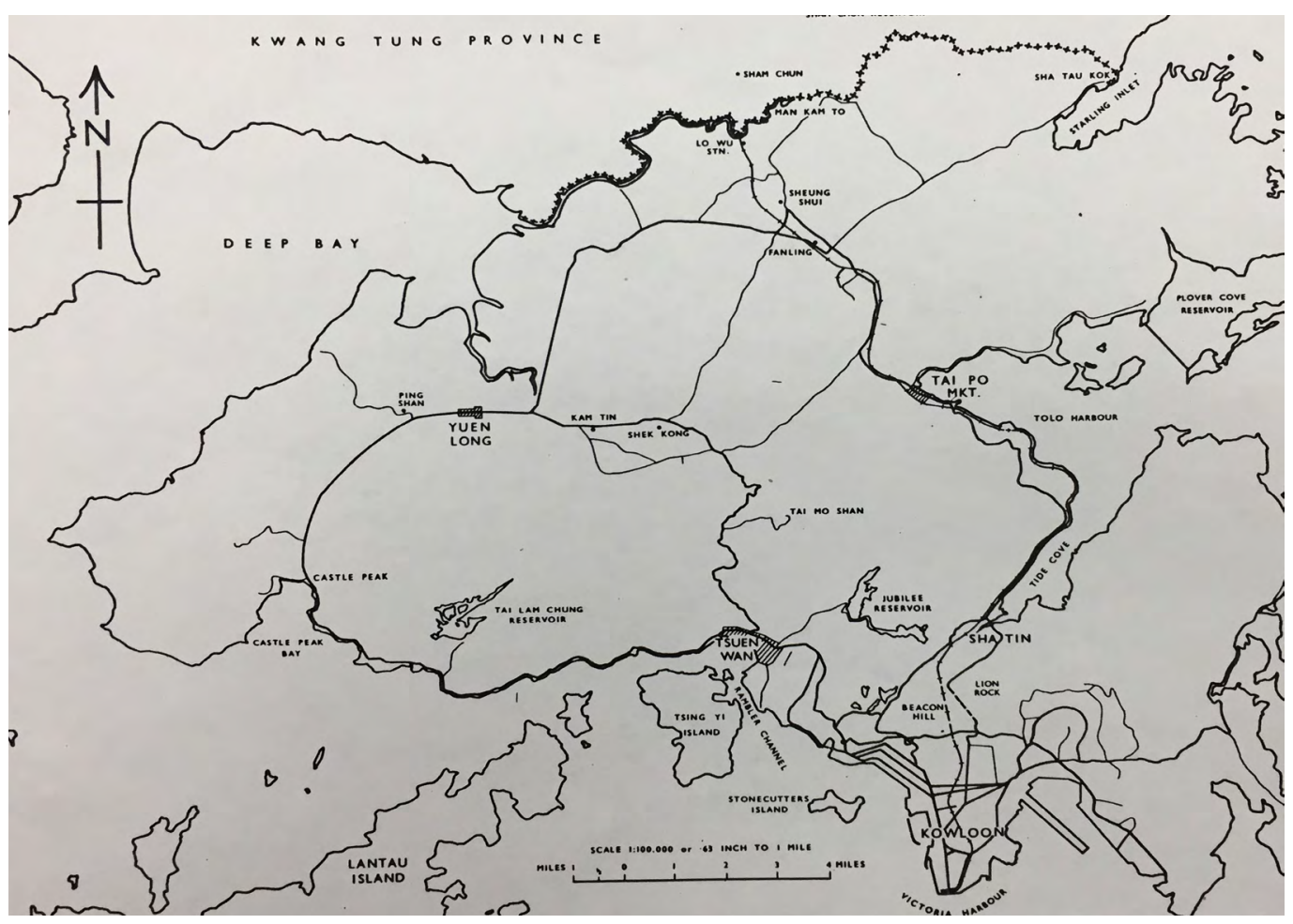

Map of Hong Kong's New Territories with border checkpoints and frontier, 1968. In Hong Kong Disturbances, 1967 (Hong Kong Government Printer, 1968). 
goods not to exceed 5 yuan in value (Shenzhen Museum 2014: 251-52). The Bamboo Curtain, like parts of the Iron Curtain, was more flexible than Cold War rhetoric allowed.

Indeed, for many whose families were divided by the Hong Kong-China border, it was less an ideological line than a bureaucratic barrier. Hundreds of thousands of people crossed at Luohu/Lo Wu every year, though regular traffic could decline in the face of China's political campaigns: in 1965-66, there were 889,249 crossings, but with the Cultural Revolution the numbers for 1966-67 fell to 565,908 (Director of Immigration 1967: 98). While outside the frontier zones it was less typical to make frequent trips from Hong Kong to China, people did travel for significant family events such as funerals. It was also customary for border officials on both sides to relax restrictions during festivals like Chinese New Year, or when school holidays permitted children to visit their parents over the summer. For local officials in Bao'an County, ties with the diaspora were channels for village investment and opportunities for United Front propaganda. Hong Kong compatriots built schools and donated goods-in-kind; a diasporic newsletter provided information on how to invest in one's hometown (Bao'an Village Dispatch, January 1959). At the height of China's Great Leap Forward famine, individual care packages mailed via the Hong Kong Post numbered about one million per month in 1961, with record-setting months exceeding two million (Hong Kong Public Records Office, HKMS 158-1-176; HKMS 158-1-214; HKRS 70-2217). While the customs administration focused mostly on the land border and its customs stations, the maritime border was literally and figuratively a more fluid space. Nowhere was this more evident than in Deep Bay, where oyster beds could be separated by 20-30 metres (Hong Kong Public Records Office, HKRS 7853-7), and in deep sea waters, where the Hong Kong Marine Police and the People's Militia might communicate by Chairman Mao's Little Red Book and together sing 'Sailing the Seas Depends on the Helmsman' (Lok 2011). Oral histories of the Hong Kong Marine Police and the Shajing oystermen both sound a familiar note: they view the discovery of escapees as rescue-the former offering biscuits and the latter rice (Lok 2011; Bai 2012: 141).

\section{Internal Border}

While China recognised the British border of Hong Kong in official terms (Guangdong Provincial Archives 204-2-22: 27), in certain contexts it was referred to as more of an internal border and a temporary condition. For example, in official histories such as the Bao'an County Gazetteer, descriptions of geography opened with the acknowledgement: 'Since Hong Kong and Kowloon are still occupied [侵占] by British imperialists, our county is a strategic line of border defence' (1960: 1). Chinese newspapers criticised Hong Kong's immigration restrictions, describing them as an affront to traditional familial relationships and kinship ties (Bao'an News, 8 September 1956). Sometimes Chinese border guards would use such political rhetoric to thwart their counterparts. Hong Kong marine policeman Lee Fung remembers verbal battles as he tried to repatriate escapees through Luohu/Lo Wu: 'They explained that Chinese people like to do tourism in China, and Hong Kong is a place in China, so therefore we in Hong Kong should welcome them' (Lee 2011). Even during moments that could potentially evolve into international incidents, such as when the 1966 kidnapping of oystermen escalated all the way to Beijing, both the British Chargé d'Affaires and the Chinese Foreign Ministry affirmed a principle that 'border questions be settled locally' (Hong Kong Public Records Office, HKRS 934-8-111). Beyond the political rhetoric that treated the border as an ideological one, the practice of the border was pragmatic: when border fences crumbled because of soil erosion, it was easier to adjust the border than to rebuild the embankment; when residents were cutting too many holes in the fence, it was better to 


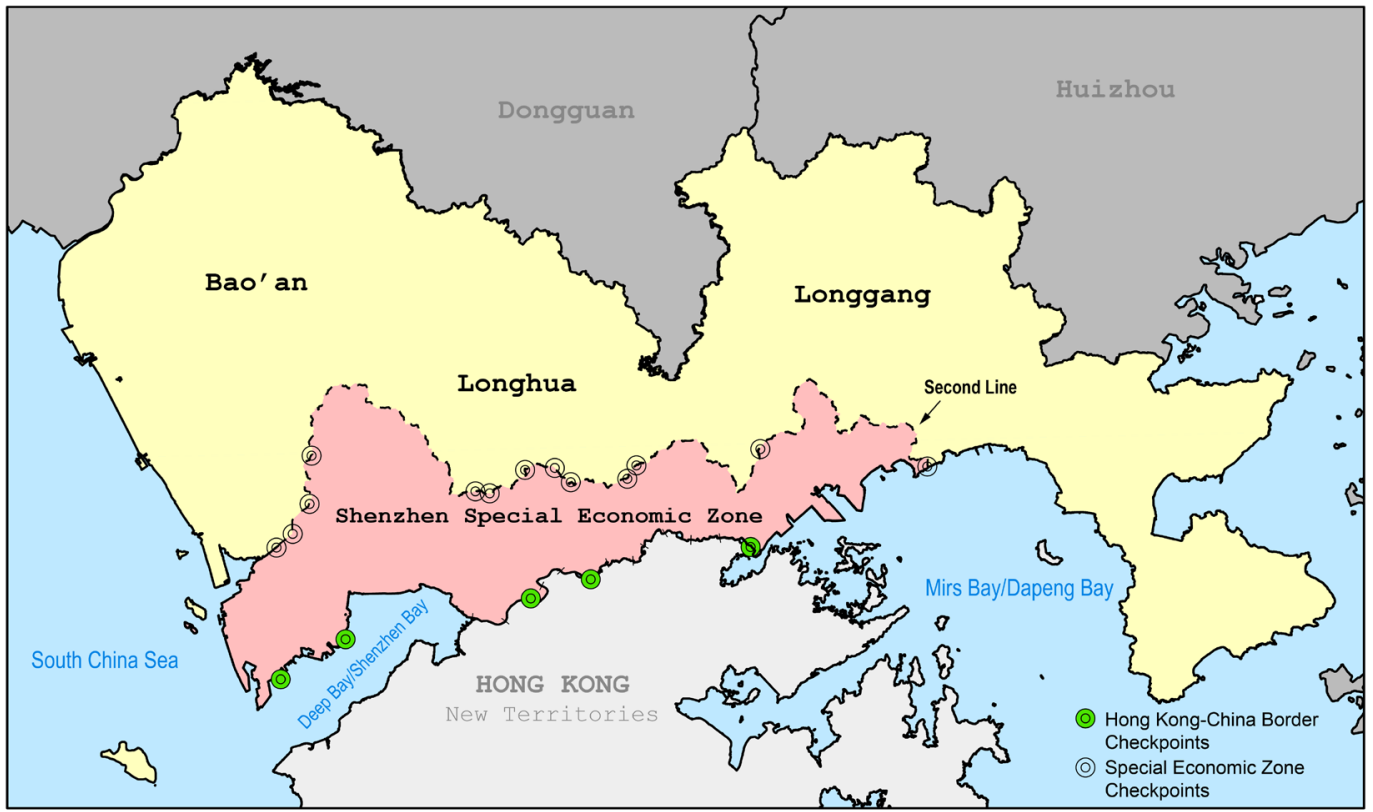

paint existing holes to make them more visible (Hong Kong Public Records Office, HKRS 1561-3766; HKRS 934-6-107).

The liminality of the border and the frontier zone was reinforced by continuing tides of migration from China to Hong Kong. In the 1960s, Hong Kong's Department of Immigration estimated that about 400 to 600 'illegal immigrants' arrived monthly, with the largest influx being just over 142,000 people in 1962 (Director of Immigration 1966: 8). In 1974, Hong Kong began to require that all Hong Kong residents carry identification cards and repatriated those entering illegally. A 'touchbase' policy remained until 1980, allowing those who made it to urban areas to stay (Faure 1997: 349-50). In the years leading up to 1980, thousands fled China via Bao'an County. The Shajing oystermen describe production teams and villages where more than half the population left, recall nights when hundreds
Map of the Shenzhen Special Economic Zone and its Second Line. Courtesy of Denise Y. Ho, 2020.

of people stood on the shore waiting for boats, and say of the flight that it was like a typhoon, fundamentally you couldn't control it' (Bai 2012: 149, 284). But concurrent with the tightening of the Hong Kong border was the construction of a new and official internal border in Bao'an County-one that encircled the Shenzhen Special Economic Zone, which was established in 1980. In 1982, construction began on this 'second line' (二线), eventually creating an 80-kilometre fence guarded by 163 watchtowers and permitting passage through eight-later, 15-checkpoints ( $\mathrm{Ma}$ and Blackwell 2017: 129; Guide for Entering and Exiting Shenzhen 1986: 14). From 1984 until it fell into disuse about 20 years later, the 'second line' bounded China's experiment with Reform and Opening Up, allowing those within its limits to benefit from new opportunities and barring from entry those without the appropriate passes; the 'second line' was 


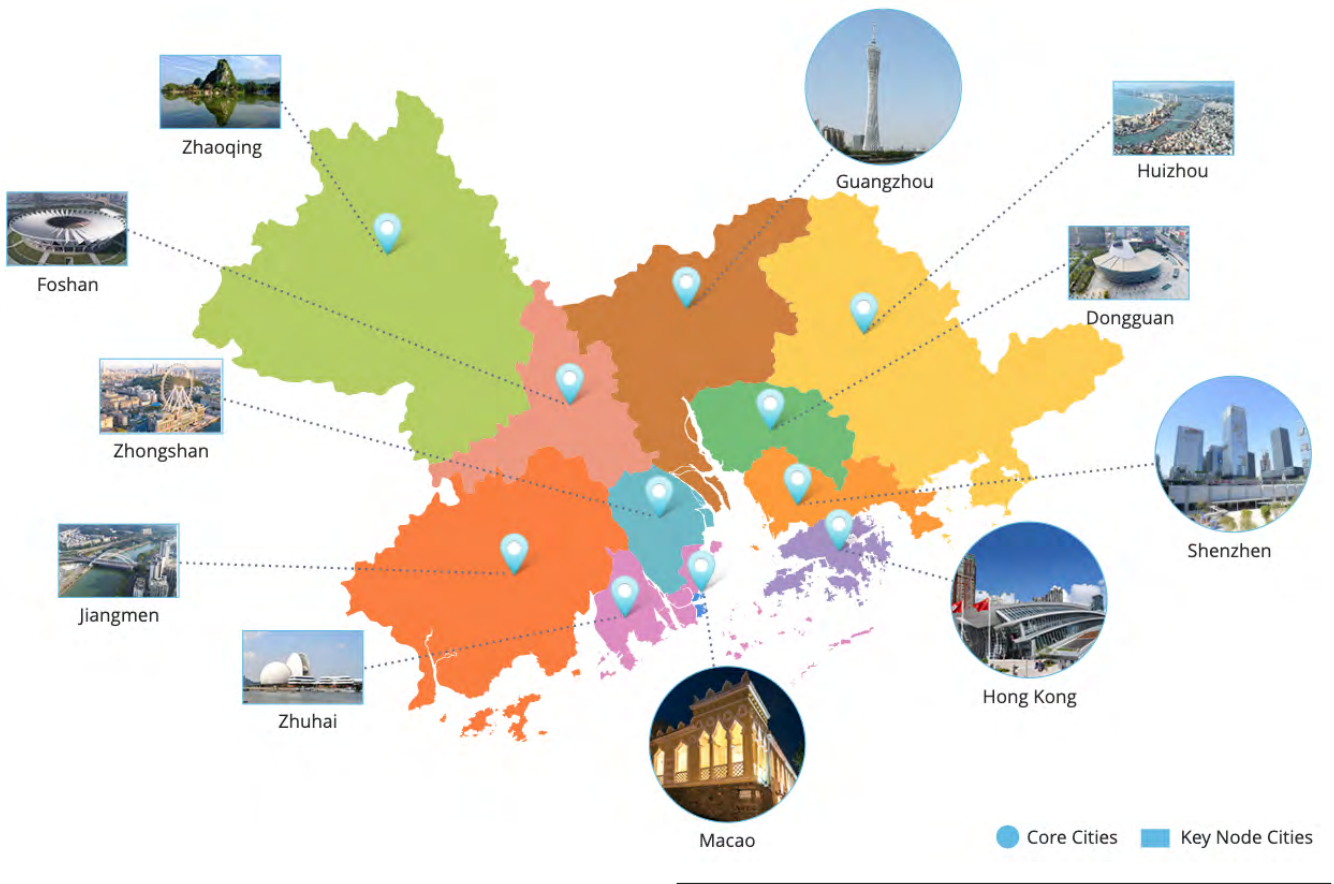

Map of the Greater Bay Area. Hong Kong

Constitutional and Mainland Affairs Bureau.

officially decommissioned in 2010 (O'Donnell and Wan 2017: 44). In some ways, Shenzhen residents who had long been able to use the Hong Kong-China border to their advantage could now benefit from their position between the international border and the internal 'second line'. The Shajing oystermen, for example, sold their wares on the Hong Kong side and purchased electronics and other manufactured goods, to be resold in Shenzhen and onwards to Dongguan and Guangzhou. With access to boats, navigational skills, and familial networks, they moved everything from electric wire to waterpipes, and bricks to concrete, when first Shenzhen and then the Pearl River Delta was 'one big construction site' (Bai 2012: 180, 150-51, 231, 269, 285-86).

With the creation of the Hong Kong Special Administrative Region in 1997, the boundary between Shenzhen and Hong Kong became a domestic one. Indeed, the 1997 changes tightened many of the threads stitched since the reform era, including cross-border relations at the village level (O'Donnell 2001: 423). But multiple institutions of an international border remain: a customs regime limits the movement of goods, including publications; international travellers require visas to enter China from Hong Kong; and the legal systems of each territory apply up to the boundary. Yet other innovations aided by technology blur the border: dedicated immigration e-channels speed through regular crossers, Hong Kong telecoms allow dual telephone numbers, and a 2016 cross-border investment channel links the Hong Kong and Shenzhen stock exchanges. Thus, while the physical and political-administrative border has persisted, an increased daily flow of people, objects, and ideas has expanded the zone of the imagined border. Since the era of Reform and Opening Up, anthropologists have documented cultural divides, from differences 
in cross-border consumption (Ma 2012) to the anxieties experienced by cross-border families (Newendorp 2008). But as anthropologist Helen Siu (2016: 348) points out, in the past decade rising standards of living in Chinese cities have created a middle class that has more in common with Hong Kongers, laying the foundation for a cultural lingua franca. The potential for integration rests on the shared cultural, economic, and social history of the Pearl River Delta. This is the bargain of China's idea of a Greater Bay Area, which is fundamentally a political project.

\section{Border Crossing}

Yet historical experience demonstrates that borders are bridged not by political directive but by shared identities, familial networks, and mutual benefit. Chinese patriotism linked 1920s Hong Kong and Guangzhou and wartime resistance connected 1940s New Territories and Bao'an. A shared sense of destiny motivated Hong Kong students to join their Guangzhou counterparts in May 1989, with the same Shenzhen-Guangzhou train tracks serving as a site for a sit-in on 5 June (Foreign Broadcast Information Service, 24 May and 6 June 1989). In the 1950s and 1960s, kinship and nativeplace networks provided care packages of food and remittances; these same channels were used to build factories and donate to hospitals in the era of reform. Since 1964, a material and symbolic system of mutual benefit is the East River-Shenzhen Irrigation Works, which pipes in Hong Kong's freshwater supply. However, such connections can be fragile. Unlike the 1898 proclamation to leave New Territories customs undisturbed (Colonial Office 1898-1900: 134) or the 1966 understanding to let local affairs in Deep Bay be resolved within the family (Hong Kong Public Records Office, HKRS 934-8-111), the top-down implementation of a Greater Bay Area threatens to turn the border back into an ideological one. For Hong Kong and Shenzhen-two megacities grappling with population pressures from below and political power from above-the challenge remains to create of the border a solution, rather than a problem. 
This text is taken from Made in China Journal: Volume 5, Issue 3, 2020, edited by Ivan Franceschini and Nicholas Loubere, published 2021 by ANU Press, The Australian National University, Canberra, Australia.

doi.org/10.22459/MIC.05.03.2020.13 